\title{
Regenerative capacity of bone marrow stem cells with or without superparamagnetic iron oxide nanoparticles after facial nerve degeneration: A narrative review
}

\author{
Noura Abd El-Latif, Mona Denewar, Rehab R. El-Zehary, Fatma M. Ibrahim \\ Oral Biology Department, Faculty of Dentistry, Mansoura University, Egypt
}

\begin{abstract}
Facial palsy can be defined as a kind of paralysis affecting facial muscles. It is termed Bell's palsy if it is unilateral. It may occur due to trauma to the facial nerve, infections as herpes zoster, neoplastic lesions, or unknown cause. It may be also associated with metabolic and systemic diseases as hypertension, toxicity, amyloidosis, alcoholism, auto-immune diseases and diabetes mellitus. Mesenchymal stem cells (MSCs) are multipotent adult stromal cells that have many benefits as an evolving treatment modality. Bone marrow stem cells (BMSCs) divide progressively in culture, and differentiate into neurons exclusively with use of a simple protocol. Most ongoing preclinical and clinical cell treatment modalities composed of local or systemic transplantation of stem or progenitor cells. In addition, they depend on the migration and retention of transplanted cells at insult areas. Nevertheless, one of the main obstacles against this modality is how to detect the fate and exact location of these cells inside the body, and how to maintain the cells at this specific site. Magnetic targeting systems, which depends on cells labelled by magnetic carriers, have been assessed as a more efficient technique for stem cell delivery to target sites. These systems depend on loading stem cells with magnetic nanoparticles and attracting them to the exact intended area within the body by placing an external magnetic field.

Superparamagnetic iron oxide nanoparticles (SPIONs) have been introduced int the last few years as a rising applicant of nanoparticles in a vast variety of medical fields as magnetic separation, drug delivery, magnetic resonance imaging (MRI) and magnetic hyperthermia. In addition, applications of SPIONs, as a site-specific drug carrier, diagnostic agent and stem cell delivery agent, receive most attention of researchers in that field. In this review, up-to-date information about Magnetic targeting of degenerated facial nerve by BMSCs labelled with SPIONs may suggest its capacity of better regeneration than injection of BMSCs alone.
\end{abstract}

Keywords: bone marrow stem cells, facial nerve, magnetic targeting, super paramagnetic iron oxide nanoparticles

\section{INTRODUCTION: FACIAL NERVE}

Facial nerve is a cranial nerve that passes in the parotid gland to provide nerve supply to the muscles of the face. It has five main branches which are: the temporal, zygomatic, buccal, mandibular, and cervical branches. Normal activity of facial muscles performs a very important function in a person's physiological, psychological, and emotional reactions. Social and vocational disabilities, which is formed from all these components, can be caused by facial disfigurement (1).

\section{FACIAL NERVE DISORDERS}

Facial nerve carries motor, sensory, and parasympathetic fibers, therefore, both functional and cosmetic impairment can be caused by facial palsy. Facial nerve palsy is clinically detected when weakness of the facial muscles is diagnosed. It can be diagnosed by pain around the ear, curving in the angle of the mouth, improper mouth closure, dryness of the eye, hyperacusis, improper taste sensation, incomplete lid closure or eye brow immobility (2). 


\section{ETIOLOGY OF FACIAL NERVE DISORDER}

Facial nerve diseases can arise from a wide variety of disorders. The origin of these disorders may be traumatic (as basal skull fractures and facial injuries) (3), neurologic (4) or infectious (5). Facial nerve degeneration can also arise from metabolic causes (as diabetes mellitus (6), hyperthyroidism (7) and hypertension (8)), neoplastic causes (9), and iatrogenic causes (as mandibular block anesthesia and other dental procedures) (10). Some chemicals can cause toxic degeneration of the facial nerve as thalidomide (11), ethylene glycol (12), arsenic intoxication (13) and local anesthesia (14).

\section{TISSUE REGENERATION}

Insults to any living tissues are counteracted by a natural sequence of actions for healing through repair or regeneration. However, natural repair and regeneration can lose adequacy and regulation in case of major trauma or surgery, leading to undesirable results as fibrosis and aging. So, recent researches are aiming to use regenerative cells to restore the living tissue, this is what is called tissue regeneration technology (15).

\section{STEM CELLS}

Stem cells are defined as the cells which have less or undifferentiated phenotype, and have the ability of self-renewal and production of different types of cells. Stem cells can be classified according to their lineage into embryonic and adult stem cells. Embryonic stem cells (ESCs) are pluripotent cells derived from the embryoblasts of the blastocyst that can be propagated endlessly in an undifferentiated state. When ESCs are cultured in a convenient environment, they can differentiate into ectodermal, endodermal and mesodermal cells. Adult stem cells are part of tissue-related cells of organism after birth. They can differentiate to the cells of their original tissue. Adult stem cell plasticity term, which evolved in the past years, means that stem cells of specific organ can differentiate into cells of other diversity of organs. This term has greatly changed the idea that tissue-specific stem cells could only differentiate into cells of the tissue source (16).

\section{NERVE TISSUE ENGINEERING}

Establishment of a more supportive environment for regenerating axons, in addition to maintaining this support for an extended period of time, is considered the main target of any stem cell treatment advance to peripheral nerve trauma. Increasing amount of stem cells around motor and sensory neurons would propably provide higher numbers of neurons for regeneration, which could aid regeneration in an additive fashion to the establishment of a favorable environment (17).

Transplantation of stem cell into muscle deprived of nerve supply may present a promising method to allow muscle reinnervation and activity. Moreover, muscle atrophy and leaving the tissue without nerve supply can be prevented over extended time intervals $(18,19)$.

\section{BONE MARROW STEM CELLS}

BMSCs are form of adult stem cells that can yield variety of cells, even if they are not mesenchymal, by differentiation, dedifferentiation, and transdifferentiation. It has been validated that they are able to produce cardiomyocytes (20), hepatocytes (21), osteocytes (22), neurons and Schwann cells (23).

Animals with peripheral nerve injury, which received topical or systemic transplantation of BMSC, showed BMSCs trasfer and specific occupying in traumatized neural areas (spinal cord and injured nerves). This is associated with an intense decrease in pain manifestations, reduction of occurrence risk of any neurochemical variation often detected in neurons during peripheral nerve injury, and a faster degeneration-regeneration process, reflected upon electromyographic readings (24). On this base, a number of researches depended on BMSCs for regeneration of the facial nerve as listed in table 1.

\section{CHALLENGES FACING STEM CELL THERAPY}

Most ongoing cell treatment modalities (whether in vivo or in vitro) composed of local or systemic transplantation of stem or progenitor cells. In addition, they depend on the transfer and habitation of transplanted cells at insult areas. Nevertheless, one of the main obstacles against this modality is how to detect the fate and exact location of these cells inside the body, and how to maintain the cells at this specific site. To overcome these obstacles, researchers were trying to find out methods to increase the occupation of transplanted cells at the intended areas for treatment in the body (32).

\section{NANOTECHNOLOGY}

Nanotechnology refers to the formulation and usage of materials, which have components of very small size, measured in the nanoscale (i.e., their sizes are up to $100 \mathrm{~nm}$ ). Nanotechnology is used nowadays in a wide variety of fields as electrical, optical, and magnetic fields as well as structural performence at the molecular and submolecular level. Their characteristics of being safe, cheap ,easily carried and administrated, give them the capacity to 
TABLE 1. Researches collected from PubMed database estimating the impact of BMSCs on facial nerve regeneration in vitro and in vivo

\begin{tabular}{|c|c|c|c|c|}
\hline $\begin{array}{l}\text { Author } \\
\text { (publication year) }\end{array}$ & & Study design & Aim & Result \\
\hline $\begin{array}{l}\text { Grosheva et al., } \\
2008(25)\end{array}$ & In vivo & $\begin{array}{l}\text { Transected facial } \\
\text { nerve model }\end{array}$ & $\begin{array}{l}\text { To evaluate whether manual } \\
\text { stimulation could be beneficial } \\
\text { after a surgical procedure for } \\
\text { treatment of large peripheral nerve } \\
\text { defects }\end{array}$ & $\begin{array}{l}\text { BMSCs failed to diminish the degree of } \\
\text { collateral axonal branching at the injury } \\
\text { region and did not correct the physiological } \\
\text { impairment }\end{array}$ \\
\hline $\begin{array}{l}\text { Aggarwal et al., } \\
2012(26)\end{array}$ & In vivo & $\begin{array}{l}\text { Facial nerve } \\
\text { paralysis model }\end{array}$ & $\begin{array}{l}\text { To study the safety profile and } \\
\text { role of BMSCs in the rehabilitation } \\
\text { of posttraumatic facial nerve } \\
\text { paralysis, which is not treated by } \\
\text { conventional therapy. }\end{array}$ & $\begin{array}{l}\text { Stem cell therapy can be used safely in } \\
\text { human beings without any adverse effects } \\
\text { on humans }\end{array}$ \\
\hline $\begin{array}{l}\text { Costa et al., } 2013 \\
(27)\end{array}$ & in vivo & Animal rat model & $\begin{array}{l}\text { To estimate histological and } \\
\text { physiological impact of BMSCs } \\
\text { with polyglycolic acid tube in } \\
\text { autografted rat facial nerves }\end{array}$ & $\begin{array}{l}\text { Schwann-like cells were associated with } \\
\text { superior outcomes. BMSC introduced in } \\
\text { neural tissue allowed maintenance of } \\
\text { former cell phenotype for six weeks. }\end{array}$ \\
\hline $\begin{array}{l}\text { Salomone et al., } \\
2013 \text { (28) }\end{array}$ & In vivo & Animal rat model & $\begin{array}{l}\text { To evaluate (BMSC) in a silicone } \\
\text { conduit for rat facial nerve } \\
\text { regeneration from isolated stumps. }\end{array}$ & $\begin{array}{l}\text { Regeneration improvement by both Ubmsc } \\
\text { and dBMSC in rats, however, uBMSC was } \\
\text { associated with superior functional results }\end{array}$ \\
\hline $\begin{array}{l}\text { Lucena et al., } \\
2014 \text { (29) }\end{array}$ & In-vitro & $\begin{array}{l}\text { Quantitative } \\
\text { phenotypic analysis }\end{array}$ & $\begin{array}{l}\text { To evaluate the plasticity of BMSCs } \\
\text { of mice in the existence of culture } \\
\text { medium conditioned with facial } \\
\text { nerve explants and fibroblast } \\
\text { growth factor-2 (FGF-2) }\end{array}$ & $\begin{array}{l}\text { BMSCs showed typical morphology and fast } \\
\text { expansion, especially the cells that were } \\
\text { subjected to a medium conditioned by the } \\
\text { facial nerve. }\end{array}$ \\
\hline $\begin{array}{l}\text { Ge, Yining et al., } \\
2018(30)\end{array}$ & In-vivo & Animal rat model & $\begin{array}{l}\text { To detect the technique of the } \\
\text { immunomodulation impact of } \\
\text { BMSCs on facial nerve trauma }\end{array}$ & $\begin{array}{l}\text { BMSCs can secrete cytokines IL-6, HGF, } \\
\text { PGE2, iNOS, and TGF- } \beta 1 \text { in an independent } \\
\text { manner. These cytokines might set } \\
\text { coordination among subsets of CD4+ T } \\
\text { cells, inhibiting neuron apoptosis, thus } \\
\text { preserving the integrity of facial nerves. }\end{array}$ \\
\hline $\begin{array}{l}\text { Li Wu et al., } 2020 \\
\text { (31) }\end{array}$ & In vivo & Animal rat model & $\begin{array}{l}\text { To study the impact of co- } \\
\text { transplantation of BMSCs and } \\
\text { monocytes in facial nerve axotomy. }\end{array}$ & $\begin{array}{l}\text { Significant improvement in the facial nerve } \\
\text { nucleus in axotomy rats, enhancing the } \\
\text { coordination of the chemotaxis, homing, } \\
\text { differentiation of BMSCs, with diminishing } \\
\text { neuronal apoptosis. }\end{array}$ \\
\hline
\end{tabular}

remodel an array of medical and biotechnology applications (33).

\section{MAGNETIC TARGETING OF MSCS}

Last few decades have witnessed the emergence of magnetic targeting systems as a prominent technique for site-specific targeting of various pharmacological agents or stem cells. With the effect of a magnetic field, it avoids reticuloendothelial system and directs the drugs or stem cells, to reach the target accurately (34). Magnetic carriers could be nanoparticles, microspheres, liposomes and emulsion. Magnetic targeting of MSCs includes the following processes: 1) isolation, growth, and preservation of MSCs in culture media; 2) magnetization of MSCs; and 3) path control of magnetized MSCs via static magnetic fields (32).

\section{SUPERPARAMAGNETIC IRON OXIDE NANOPARTICLES}

Superparamagnetic nanoparticles are those which have size less than $30 \mathrm{~nm}$, i.e., their magnetization happens only when an external magnetic field is present. This is a beneficial property for biological applications. Therefore, SPIONs are crucial materials for several medical purposes of MSCs with magnetic targeting technology. In addition, they can also be used as contrast agents for MSC labeling and tracking in the body due to the powerful signal they generate in magnetic resonance imaging (MRI) (35).

SPIONs has many beneficial properties as easy synthesis, biocompatibility, multifunctionality, and possibility of further surface modification with various chemical agents, SPIONs can aid in many domains of medicine. SPIONs have also some disadvantages, such as their high uptake by macrophages. However, they sound to be very promising in stem cell treatment modalities depending on the results the current researches (35).

\section{THE USE OF BMSCS WITH SPIONS IN NERVE REGENERATION}

Zhang et al. (2016) studied the impact of magnetic targeting of NT3 gene-transfected BMSCs through lumbar puncture in a rat study design of SCI. They 
proved that delivery of transplanted BMSCs to the exact injury site, in addition to performing cell imaging via MRI, could be achieved using magnetic targeting cells delivery system. Moreover, the study markedly enhance functional recovery and nerve regeneration, in comparison with transplanting NT3 gene-transfected BMSCs without magnetic targeting system (36). These outcomes may put in mind that the use of BMSCs with SPIONs could be a promising method of treating other degenerated nerves (i.e. facial nerve). also reported that this treatment modality could

\section{CONCLUSIONS}

BMSCs therapy is considered as a promising choice for treatment of facial nerve degeneration. However, localization of the injected cells within the injury site remains a challenge against the effectiveness of this treatment. We suggest that the use of BMSCs with SPIONs as a magnetic targeting system may allow definite delivery of stem cells to the injured facial nerve, and so, enhancing the effectiveness of the treatment.

Conflict of interest: none declared Financial support: none declared

\section{REFERENCES}

1. Chacon MA, Echternacht SR, Leckenby Jl. Outcome measures of facial nerve regeneration: A review of murine model systems. Ann Anat. 2020 Jan;227:151410.

2. Davies J, Al-Hassani F, Kannan R. Facial nerve disorder: a review of the literature. IJS Oncology. 2018 Oct 1;3(7):e65..

3. Langhals NB, Urbanchek MG, Ray A, Brenner MJ. Update in facial nerve paralysis: tissue engineering and new technologies. Curr Opin Otolaryngol Head Neck Surg. 2014 Aug;22(4):291-9.

4. Sardana V, Bhattiprolu RK. Dengue Fever with Facial Palsy: A Rare Neurological Manifestation. Ann Indian Acad Neurol. 2019 Oct-Dec; 22(4):517-519.

5. Lima MA, Silva MTT, Soares CN, Coutinho R, Oliveira HS, Afonso L, Espíndola O, Leite AC, Araujo A. Peripheral facial nerve palsy associated with COVID-19. J Neurovirol. 2020 Dec;26(6):941-944.

6. Tsunoda K, Omote Y, Hishikawa N, Ikegami K, et al. Diabetic painful truncal neuropathy with hypohidrosis and facial palsy. Neurology and Clinical Neuroscience. 2020 May;8(3):155-7.

7. Gon Y, Sakaguchi M, Oyama N, Mochizuki H. Diagnostic Utility of Contrast-enhanced 3D T1-weighted Imaging in Acute Cerebral Infarction Associated with Graves Disease. J Stroke Cerebrovasc Dis. 2017 Feb;26(2):e38-e40.

8. Kobayashi H, Fujii K, Kobayashi M, Saito N, et al. Facial nerve palsy associated with atomoxetine-induced hypertension. Brain Dev. 2019 Mar;41(3):310-312.

9. Patel KB, Gaidis A, Stephens A, Thompson TZ, Williams H, Rungruang $B$. A report of Bell's Palsy triggered by leptomeningeal metastases from recurrent high grade serous ovarian cancer. Gynecol Oncol Rep. 2018 Oct 19;26:82-86.

10. Gaudin RA, Remenschneider AK, Phillips K, Knipfer C, Smeets R, Heiland M, Hadlock TA. Facial palsy after dental procedures - Is viral reactivation responsible? J Craniomaxillofac Surg. 2017 Jan; 45(1):71-75.

11. Al Mosawi AJ. The syndrome of congenital facial palsy and unilateral anotia. Clin Res Trials. 2019;5:1-2.

12. Basnayake BMDB, Wazil AWM, Nanayakkara N, et al. Ethylene glycol intoxication following brake fluid ingestion complicated with unilateral facial nerve palsy: a case report. J Med Case Rep. 2019 Jul 3;13(1):203.

13. Rajavardhan R, Mamadapur A, Shyamala N. Acute Arsenic Suicidal Poisoning - A Rare Case. International Journal of Medical and Dental Sciences. 2021 Jan 29;10(1):1961-5.

14. Chalhoub W, Korbani ET. Transient immediate facial nerve paralysis after local anesthesia in a retro-auricular minor surgery. JAAD Case Rep. 2020 May 18;6(7):608-611.

15. Kwon SG, Kwon YW, Lee TW, Park GT, Kim JH. Recent advances in stem cell therapeutics and tissue engineering strategies. Biomater Res. 2018 Dec 19;22:36.

16. Zakrzewski W, Dobrzyński M, Szymonowicz M, Rybak Z. Stem cells: past, present, and future. Stem Cell Res Ther. 2019 Feb 26;10(1):68.

17. Jahromi M, Razavi S, Bakhtiari A. The advances in nerve tissue engineering: From fabrication of nerve conduit to in vivo nerve regeneration assays. J Tissue Eng Regen Med. 2019 Nov; 13(11):2077-2100.

18. Salehi M, Bagher Z, Kamrava SK, Ehterami A, et al. Alginate/chitosan hydrogel containing olfactory ectomesenchymal stem cells for sciatic nerve tissue engineering. J Cell Physiol. 2019 Jan 31;234(9):15357-68.

19. O'Rourke C, Day AGE, Murray-Dunning C, et al. An allogeneic 'off the shelf' therapeutic strategy for peripheral nerve tissue engineering using clinical grade human neural stem cells. Sci Rep. 2018 Feb 13; 8(1):2951.

20. Neshati V, Mollazadeh S, Fazly Bazzaz BS, de Vries AAF, et al. MicroRNA-499a-5p Promotes Differentiation of Human Bone Marrow-Derived Mesenchymal Stem Cells to Cardiomyocytes. Appl Biochem Biotechnol. 2018 Sep;186(1):245-255.

21. Li F, Liu Y, Cai Y, Li X, Bai M, Sun T, Du L. Ultrasound Irradiation Differentiation of Human Bone Marrow Mesenchymal Stem Cells. Ultrasound Med Biol. 2018 May;44(5):1044-1052.

22. Zhang $M$, Jia $L$, Zheng Y. circRNA Expression Profiles in Human Bone Marrow Stem Cells Undergoing Osteoblast Differentiation. Stem Cell Rev Rep. 2019 Feb;15(1):126-138.

23. Xue J, Yang J, O’Connor DM, Zhu C, Huo D, Boulis NM, Xia Y. Differentiation of Bone Marrow Stem Cells into Schwann Cells for the Promotion of Neurite Outgrowth on Electrospun Fibers. ACS Appl Mater Interfaces. 2017 Apr 12;9(14):12299-12310.

24. Huh Y, Ji RR, Chen G. Neuroinflammation, Bone Marrow Stem Cells, and Chronic Pain. Front Immunol. 2017 Aug 21;8:1014.

25. Grosheva M, Guntinas-Lichius O, Arnhold S, Skouras E, et al. Bone marrow-derived mesenchymal stem cell transplantation does not improve quality of muscle reinnervation or recovery of motor function after facial nerve transection in rats. Biol Chem. $2008 \mathrm{Jul}$; 389(7):873-88.

26. Aggarwal SK, Gupta AK, Modi M, Gupta R, Marwaha N. Safety profile of bone marrow mononuclear stem cells in the rehabilitation of patients with posttraumatic facial nerve paralysis-a novel modality (phase one trial). J Neurol Surg B Skull Base. 2012 Aug;73(4):245-52.

27. Costa HJ, Bento RF, Salomone R, Azzi-Nogueira D, et al. Mesenchymal bone marrow stem cells within polyglycolic acid tube observed in vivo after six weeks enhance facial nerve regeneration. Brain Res. 2013 May 13;1510:10-21.

28. Salomone R, Bento RF, Costa HJ, Azzi-Nogueira D, et al. Bone marrow stem cells in facial nerve regeneration from isolated stumps. Muscle Nerve. 2013 Sep;48(3):423-9.

29. Lucena EE, Guzen FP, Cavalcanti JR, Marinho MJ, et al. Plasticity of mesenchymal stem cells from mouse bone marrow in the presence of conditioned medium of the facial nerve and fibroblast growth factor-2. ScientificWorldJournal. 2014;2014:457380.

30. Ge Y, Zhang Y, Tang Q, Gao J, Yang H, Gao Z, Zhao RC. Mechanisms of the Immunomodulation Effects of Bone Marrow-Derived Mesenchymal Stem Cells on Facial Nerve Injury in Sprague-Dawley Rats. Stem Cells Dev. 2019 Apr 1;28(7):489-496. Combined with Hepatocyte Growth Factor Accelerate the Hepatic 
31. Wu L, Han D, Jiang J, Xie X, Zhao X, Ke T, Zhao W, Liu L, Zhao W. Co-transplantation of bone marrow mesenchymal stem cells and monocytes in the brain stem to repair the facial nerve axotomy. Eur J Histochem. 2020 Jun 19;64(s2):3136.

32. Silva LH, Cruz FF, Morales MM, Weiss DJ, Rocco PR. Magnetic targeting as a strategy to enhance therapeutic effects of mesenchymal stromal cells. Stem Cell Res Ther. 2017 Mar 9;8(1):58.

33. Khan I, Saeed K, Khan I. Nanoparticles: Properties, applications and toxicities. Arabian journal of chemistry. 2019 Nov 1;12(7):908-31.

34. Hasan A, Morshed M, Memic A, Hassan S, Webster TJ, Marei HE. Nanoparticles in tissue engineering: applications, challenges and prospects. Int J Nanomedicine. 2018 Sep 24;13:5637-5655.
35. Dulińska-Litewka J, Łazarczyk A, Hałubiec P, Szafrański O, Karnas K, Karewicz A. Superparamagnetic Iron Oxide Nanoparticles-Current and Prospective Medical Applications. Materials (Basel). 2019 Feb 19;12(4):617.

36. Zhang RP, Wang LJ, He S, Xie J, Li JD. Effects of Magnetically Guided, SPIO-Labeled, and Neurotrophin-3 Gene-Modified Bone Mesenchymal Stem Cells in a Rat Model of Spinal Cord Injury. Stem Cells Int. 2016;2016:2018474. 